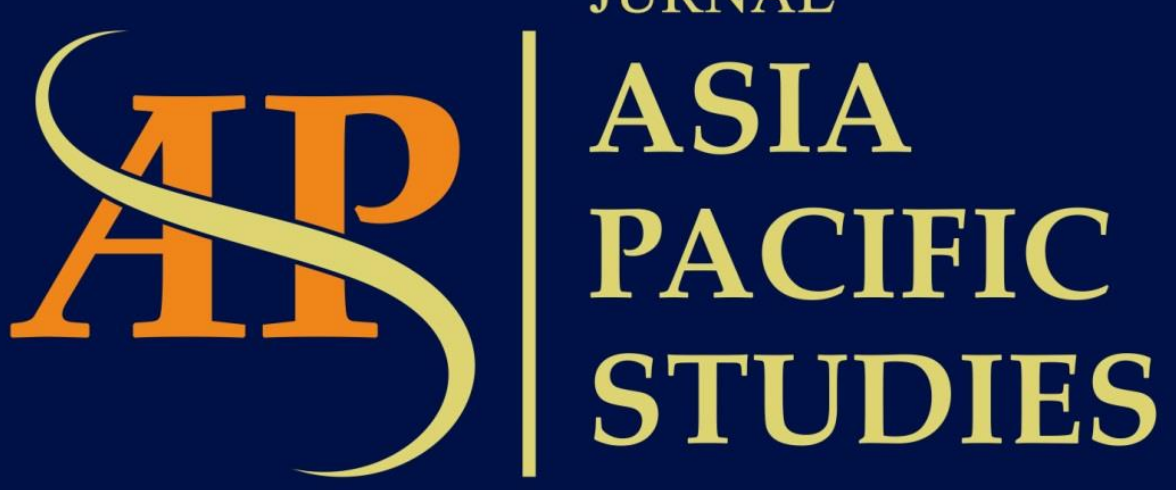

Journal of International Relations Study Program Faculty of Social and Political Sciences Universitas Kristen Indonesia

Volume 4| Number 1 | January- June 2020 


\begin{tabular}{r|l} 
Jurnal Asia Pacific Studies & Volume 4 Number 1/January - June 2020 \\
http://dx.doi.org/10.33541/japs.v4i1.1570 & pp. $60-71$
\end{tabular}

\title{
APEC: INDONESIA AS A BALANCER AMONG US-CHINA
}

\author{
Adellia Monika \\ Ilmu Hubungan Internasional, Fakultas Ilmu Sosial dan Ilmu Politik, Universitas Islam Negeri Syarif \\ Hidayatullah Jakarta, Kampus 2, Ciputat Timur, Tangerang Selatan, Banten, 15419, Indonesia \\ adelliamonika26@gmail.com
}

\begin{abstract}
APEC is an international organization located in the Asia Pacific region. Its member countries are affiliated with the intention of not only developing the regional economy but also making the region stable, because the Asia Pacific region is a busy area visited by international community entities, from developed to developing countries. This research will discuss the role of Indonesia as a counterweight to the interests of the United States and the People's Republic of China, especially in the economic fields of which each country is incorporated in APEC. Because, we know the dominance of the policies issued by the United States and the People's Republic of China in recent years has been very influential both in the international and regional order. The method used is qualitative by conducting a literature study. The approach or theory used in analyzing the discussion is the Concept of Interdependence and Neoliberal Institutionalism. The purpose of this study is to examine the extent of Indonesia's role in efforts to create regional stability between two countries that have more power such as the United States and the People's Republic of China. The results of this study will outline the benefits, opportunities and challenges of Indonesia in APEC membership and its impact on its relationship with the United States and the People's Republic of China.
\end{abstract}

Keywords: APEC, Interdependence, Neoliberal Institutionalism, Indonesia, United States, China

\begin{abstract}
Abstrak
APEC adalah salah satu organisasi internasional yang berada di kawasan Asia Pasifik. Negara-negara anggotanya tergabung dengan maksud tidak hanya mengembangkan ekonomi kawasan tapi juga menjadikan kawasan tersebut stabil, sebab kawasan Asia Pasifik merupakan kawasan yang ramai disinggahi para entitas masyarakat internasional, dari negara-negara maju hingga berkembang. Penelitian ini akan membahas mengenai peran Indonesia sebagai penyeimbang kepentingan Amerika Serikat dan Republik Rakyat Tiongkok, terutama di bidang ekonomi yang masing-masing negara tersebut tergabung dalam APEC. Sebab, kita ketahui dominasi dari adanya kebijakan yang dikeluarkan oleh Amerika Serikat dan Republik Rakyat Tiongkok beberapa tahun terakhir ini sangat berpengaruh baik di tatanan internasional maupun kawasan. Metode yang digunakan adalah kualitatif dengan melakukan studi literatur. Pendekatan atau teori yang digunakan dalam menganalisa pembahasan adalah Konsep Interdependensi dan Neoliberal Institusionalisme. Tujuan Penelitian ini adalah meninjau sejauh mana peran Indonesia dalam upaya menciptakan stabilitas kawasan di antara dua negara yang memiliki power lebih seperti Amerika Serikat dan Republik Rakyat Tiongkok. Hasil penelitian ini akan menguraikan manfaat, peluang dan tantangan Indonesia dalam keanggotaan APEC serta dampaknya terhadap hubungannya dengan Amerika Serikat dan Republik Rakyat Tiongkok.
\end{abstract}

Kata Kunci: APEC, Interdependensi, Neoliberal Instutisionalisme, Indonesia, Amerika Serikat, Tiongkok

\section{Introduction}

In the study of International Relations, the incorporation of entities or the international community in a particular cooperation or forum is inseparable from the interests or roles that an entity wishes to play. In addition to the nature of these entities prioritizing their needs, 
some of them realize that taking on the role of balancing between two interested entities will defuse the tendency to engage other entities which if not followed up will cause crucial problems both on the international order, region and in the area of the parties involved. Therefore, this research will discuss how Indonesia plays an important role as an intermediary between the interests of the United States and China in the Asia Pacific region, especially in the APEC forum. What kind of impact will arise from these actions and how will they affect Indonesia's relations with the two countries (United States and China) both bilaterally and regionally at the APEC forum.

APEC is an abbreviation of Asia Pacific Economic Cooperation, which is a forum for cooperation of nations in the Asia Pacific region in the economic field. APEC was officially formed in November 1989 in Canberra, Australia. The dominant factor driving the birth of APEC is the fear of the failure of the Uruguay round of negotiations which could result in increased protectionism and the emergence of trade groups such as the European Single Market and the North American Free Market and major changes in the political and economic fields that are happening and taking place in the Union Soviet and Eastern Europe. These two factors underlie the birth of APEC, an international cooperation forum intended to enhance economic cooperation in the Asia Pacific region, especially in the fields of trade and investment. That is why APEC can be regarded as an international forum with a focus on economic and not political issues. Its membership is open and its activities emphasize more on cooperation in the economic field. (Atiqah 2017, 8-9).

At present, APEC has 21 members, namely, Australia, Brunei Darussalam, Canada, Indonesia, Japan, South Korea, Malaysia, New Zealand,

Philippines, Singapore, Thailand, United States, Republic of China (Chinese Taipei), Hong Kong, People's Republic of China, Mexico, Papua New Guinea, Chile, Peru, Russia and Vietnam. In view of the countries that joined it, it was clearly seen that not only the developed countries in the economy were incorporated in APEC, but developing countries also participated in it.

APEC members are called "Economics" because every member interacts as an economic entity, and not as a country that tends to use political instruments in every policy. However, as we know, every entity that joins it has an ideology and foreign policy whose role cannot be separated from political tendencies as a country even in certain forums such as APEC.Therefore, many things that we can see from the countries that are members of APEC are trying to achieve their interest goals, especially for example countries that have more power like the United States and China both its dominance in politics and the international economy.

Then, with regard to Indonesia as one of the countries that joined the APEC forum, it became an important focus in this research, whether Indonesia has a progressive role as a balancing partner between the two countries that have strong power (the United States and China) or even become a predator on his own country.

As said by the Coordinating Minister for Maritime Affairs and Investment, Luhut Binsar Pandjaitan, Indonesia is big enough not to be forced to take sides, even among powerful countries. As an emerging Asian middle power, Indonesia must maintain its diplomatic freedom to take action. Slipping into the sphere of any exclusive influence, both the US and China will destroy the influence that Indonesia has in its relations with these two world powers. There is nothing special about Indonesia's position. This is how the middle power behaves, if they want to become a middle power (Mata Mata Politik 2018).

The statement of the Coordinating Minister for Maritime and Investment was almost in line with the statement issued by the Chairman of APEC Business Advisory Council (ABAC) Indonesia, Anindya Bakrie, on the sidelines of the ABAC II Meeting in Jakarta, Indonesia. He stated that Indonesia could be a balance between the two world economic 
powers, China and the United States (US) at the Asia Pacific Economy Cooperation (APEC) forum. As the country with the largest economy in Southeast Asia, Indonesia has a significant role in fighting for its interests related to digital issues, inclusiveness, and empowering women in micro and small businesses (Berita Satu 2019).

However, this position is inseparable from the challenges of Indonesia as a developing country. Asia-Pacific is a bustling trading area. Moreover, there are still many developing countries. On the other hand, domination by countries with more developed economies will have a significant influence to match the economies in other regions. Departing from all the arguments above, in this research will focus more on: What is the role of Indonesia as a 'balancer' label between two countries that have more power?

\title{
2. Literatur Review
}

In this research, the authors use the Concept of Interdependence and Neoliberal Institutionalism Theory in analyzing the phenomena that occur.

\subsection{Interdependence Concept}

Take arguments through Introduction to International Relations Theories and Approaches Book, "Interdependence means mutual dependence: peoples and governments are affected by what happens elsewhere, by the actions of their counterparts in other countries. Thus, a higher level of transnational relations between countries means a higher level of interdependence. That also reflects the process of modernization, which usually increases the level of interdependence between states" (Jackson dan Sorensen 2013: 106).

One of the main concepts that can be used to describe the current nature of the international system is the concept of interdependence. This concept assumes that the state is not an independent actor as a whole, but that the state is interdependent with each other. There is no country that can fulfill all its own needs, each of them will certainly depend on the resources and products of other countries. Therefore, policies issued by one country will have a quick and serious effect on other countries, even domestic policies can have wider implications for other countries. In connection with this research, APEC is a forum that has a very strong dependency with fellow member countries (Polii 2015: 100-101).

Therefore, in analyzing the role played by Indonesia, the United States and China cannot be separated from the overall influence of members who are also members of APEC.

\subsection{Neoliberal Institusionalisme Theory}

\begin{abstract}
"Neoliberal institutionalism (NLI) is an umbrella term for liberal research programs in the study of international relations (IR) that focus on the cooperative role of institutions. At its core, NLI argues that international cooperation is possible and most readily achievable, with the creation and maintenance of international institutions broadly defined. Both formal and informal institutional arrangements are the subjects of NLI analysis" (Janik \& Folker 2011: 2).
\end{abstract}

This theory assumes that the state voluntarily makes and submits to an institution that has a collective goal and builds a mechanism to achieve it. Informal institutional arrangements, or regimes, are also voluntarily made by the state and constitute an implied and explicit set of principles, norms, rules and procedures where the expectations of actors meet in certain issue areas. An established regime exists in the field of capitalist free trade issues, for example, because both formal and implicit institutions, principles, norms, rules, and procedures that are shared collectively are the foundation of these activities. 
Therefore, Indonesia as one of the countries joining APEC can still have an important influence where its policies or interests can also be agreed upon by other member countries which is related to the United States and China.

\subsection{Literatur Review}

According to research conducted by Restilia Polii in a journal that has been investigated by her entitled Analisis Kepentingan Indonesia Bergabung Dalam APEC written in 2015, discusses how the debate between academics and practitioners of International Relations regarding why Indonesia would like to join the Asia Pacific Economic Cooperation (APEC) until this time is still not over. There are groups who are optimistic and also pessimistic. The focus of this research is more in discussing what exactly the interests of Indonesia to join the APEC, which will be seen from economic interests, as well as political interests. Theories used in his research are Neoliberal Institutionalism Theory and the Concept of Interdependence. Where she considered that APEC member countries have similarities in economic interests, namely developing free trade and investment as well as increasing small and medium businesses, having an attachment in the success of APEC programs for the welfare of their nation's people, having characteristics in information and addressing problems, has full dependence on cooperation to maintain global economic stability. This situation is a situation where the relationship between one actor with another actor needs each other and creates a situation of mutual influence.

In line with the writings discussed in this journal, the difference lies in the focus of the implications, where the writer focuses more not only on Indonesia's interests in the APEC forum in general as written by Restilia Polii. This also relates to the interests of the United States and China also within it.

Then, the writing in this study was also enriched by Atiqah's literature with her journal entitled Sejarah APEC dan Tantangan yang Dihadapinya, written in 2017. In his research she discusses issues that include the effectiveness of APEC as a means of developing countries to improve their economic capabilities in the face of liberalization trading. In addition, she also tried to identify the motivating and hindering factors of APEC economic members in utilizing their membership in the APEC forum as an effort to improve their ability to face the era of trade liberalization. In studying the phenomena that occur, he uses the Liberalization Theory, the theory of Free Trade (free trade), as said by the liberals, is a condition where through trade without obstruction of the welfare state protection policy can be disseminated, because by adhering to the concept of comparative advantage each country will be able ensure their respective advantages in trading. This also happens to APEC countries, of course, each APEC member country seeks to ensure the trade benefits of each country. And finally, she also uses the concept of the region (Regionalism) in understanding the phenomena under study.

As an addition to the literature, the research conducted by Atiqah also has differences in the focus of implications in outline. Atiqah presents his work by discussing APEC in general terms as an entity of regional organizations that is so crowded and how the direction of its policies should be. Whereas the writer focuses more on the topic of how Indonesia positions itself with the United States and China in the APEC forum.

Then, this literature review was enriched by Baiq LSW Wardhani's literature with a journal entitled APEC 2020 Bagi Indonesia: Mitra atau Pemangsa, written in 2006. Wardhani discusses various problems that are being and will be faced by Indonesia as a country in the face of trade liberalization in 2020 with details the formulation of the problem is how Indonesia's position in APEC in 2020, whether APEC can be an economic development partner for the welfare of the Indonesian people, or vice versa, APEC is only a predator of the national economy. In his work he concluded that the joining of Indonesia in APEC was based 
more on pragmatism than ideological considerations. Indonesia tends to only follow the developments that occur around it rather than considering self-strength. The free market economy is not an effective recipe for the underdeveloped Indonesian economy like Indonesia. But with Indonesia's decision to join APEC, this decision cannot be withdrawn. So that any risk that will occur must be able to be overcome.

\section{Research Methods}

This journal use a qualitative approach. Qualitative research can be interpreted as a research method that does not rely on the process of quantification of data both in the process of data collection and in the process of data analysis. According to Alan Bryman, qualitative research is not done by calculating or measuring statistical data to explain the relationship of one thing to another thing, but qualitative research focuses more on the meaning in the form of words that can give an idea and / or explanation of a situation that is the focus research. Qualitative research methods emphasize context description because detailed discussion is very important in showing the significance of the research subject and providing explanations about the context in which an event that is the focus of the research occurs (Putri 2019: 134).

\section{Results and Discussion}

\subsection{APEC as a International Organization}

In the last decade, efforts to integrate the economy through the formation of Free Trade Agreements (FTAs) and Regional Trading Agreements (RTAs) have become a global trend (Prasetyo 2011: 1). This phenomenon causes countries to compete to form economic integration in response to globalization and competitiveness. Whether we realize it or not, it has become a paradigm in most countries in the world that in the midst of strong global competition it is important to secure its position in both international politics and the economy. This trend was seen in the Asia Pacific region during the crisis that occurred in Asia in 1997, where the demand for rapid movement of goods and services led to the need for faster and greater market access, as well as increased economic dependence between countries.

APEC as one of the answers to the problems and issues for the economic cooperation forum in the Asia Pacific region that has been taken into account in recent years. With its focus on discussing economic issues, especially efforts to establish trade liberalization and investment in the region classified as exist where not only developing countries are involved in it but also developed countries in the economy such as the United States and China.

The process to describe the institutionalization of APEC activities can be seen from the Declarations and Statements of the Annual Leader's Declarations, Annual Ministerial Meetings, and Sectoral Ministerial Meetings. Starting from the first meeting (Ministerial Meetings) in 1989 in Canberra, Australia. The meeting discussed four major agendas relating to World and Regional Economic Development, Global Trade Liberalization (Role of the Asia Pacific Region), Opportunities for Regional Cooperation in Specific Areas, and Future Steps for Asia Pacific Economic Cooperation. Until 2019 yesterday, discussing about Digital Society, Integration 4.0, Women, SMEs and Inclusive Growth and Sustainable Growth.

While the institutional structure of APEC has been substantially strengthened, the institutionalization process has not yet been achieved smoothly. In fact, from the start, there were basically different views about the direction and methods for APEC's growth. On the one hand, members of "Western" countries, especially the United States, are very fond of the 
type of regional economic organization that consists of organs with clear mandates and whose operations are carried out through legally binding instruments and decisions. Asian countries, on the other hand, prefer the Asian approach, that is, spontaneous, reconciling, informal, advising, and oriented towards a consensus approach. With regard to these two matters, however the nature and function of international institutions depends on the intentions and initial objectives formed as well as the strong role of the voice that can influence opinion in the forum for participants.

As such, none other than the view of institutional development at APEC reflects the economic expectations of its members in which there will be many different political processes clashing, stages of economic development and cultural background in each country. Nevertheless, APEC tries to unite gradually and create a new model of institutional-regional development.

As analyzed above, the APEC process characterizes the development of APEC which consists of two different approaches to institutional development, but that is more influenced by the Asian style than the Western style. This happened not only because ASEAN had taken an important role in APEC from the beginning, but also because the Asia-Pacific region had its own characteristics, namely its socio-political diversity, various levels of economic development, and markets driven by the process of economic integration. Therefore, it is difficult for APEC to take a legalistic and institutional integration approach such as the EU and NAFTA. However, these two approaches, despite their enormous differences, have started to join together since the Seattle Meeting in 1993, becoming entirely new approaches to institutional development. From this perspective, APEC will institutionalize in a unique way that is different from Asian and Western styles.

APEC not only has two different approaches to building institutions as mentioned above, but also has two different aspects of its activities. The scope of APEC's activities has grown rapidly, and currently deals with a variety of fields, from economic cooperation to liberalization and facilitation of trade and investment. In the area of economic cooperation, APEC must continue functional institutionalization, to promote its various work programs effectively and efficiently. Also, each member economy is now required to implement an Action Agenda to achieve APEC's long-term goals in trade, free and open investment. Here, APEC must remain as a consultative forum that adjusts the economic policies of each member.

There is no doubt that APEC is an international institution to promote the most active economic cooperation in efforts to liberalize, facilitate trade and investment in the AsiaPacific region. However, the informality of APEC's legal basis makes it difficult to regard associations as "international organizations" in the traditional sense of international law, which would certainly classify APEC as one of "other institutions" rather than ordinary international intergovernmental organizations. Modern international law has its historical roots in inter-state law among Christian countries in Europe, and as such, most non-Western countries, such as ASEAN countries, have almost no chance of forming existing international legal rules. However, in the process of institutionalizing APEC, Western members and Asian members have been asked to work together to establish new rules and procedures. Thus, the existence of APEC as an international institution strongly suggests alternative models of institutional development with a background in traditional international law, just as the concept of "soft law" would challenge traditional traditional sources of international law.

It should be noted that the structure and function of certain institutions and the scope of their power and decision-making procedures depend on the international, regional and other communities, which form the basis of this institution. Therefore, it must be recognized that different societies will lead to different institutional development styles and that international institutions must be understood in response to changing needs and interests of 
their members. In this regard, APEC offers a very important and challenging case for the study of the law of international organizations during a period of important change in Asia and in the world.

\subsection{The United States, The People's Republic of China, and APEC}

The rise of China is changing the geopolitical landscape of the Asia-Pacific region. How the United States and China manage their relations in the coming years will affect whether peace, stability and prosperity will continue, or whether their competition will cause tension, conflict, or even military clashes between the two Great Powers. Despite the increasing economic interdependence and many official dialogues between Beijing and Washington, bilateral relations have become tense in recent years due to large differences in various issues.

The Asia-Pacific region has some of the highest-growth markets and the largest population in the world, but many of the economies are still underdeveloped. Two new approaches to accelerating growth are in negotiations where one is led by the United States and one is led by China. This phenomenon can be seen from the leadership of trade such as the existence of the Trans-Pacific Partnership (TPP) which is a regional agreement aimed at harmonizing regulations, trade liberalization and promoting private investment among Pacific countries. Promoted by the United States (currently excluding China), and is intended to facilitate growth in trade that is projected to reach US \$ 10 trillion annually in 2020 . On the other hand the phenomenon in the Asia Pacific is about led investment such as the Asian Infrastructure Investment Bank (AIIB) which is an international financial institution focused on Asia, funded by the government and private capital, to provide capital for development projects throughout Asia. Proposed by China (not currently including the United States) and designed to help meet the needs that will be projected at US $\$ 8$ trillion in infrastructure investment in the region over the next 20 years.

Which proposal comes out as trending, relating to new regulations, trade regulations and investments will be on the road that will affect anyone who wants to do business in or with the Asian region, where the effect will affect the health of the global economy.

Both AIIB and TPP will involve setting up new regulatory systems in the world's most populous and fastest growing regions, potentially affecting everything from product standards to employee benefits, environmental laws to taxes, government procurement to e-commerce . No wonder they attract a lot of attention from the government and business.

In general, nothing complicated, everything went smoothly. Negotiations for the TPP began in 2005, but stalled in the US Congress, where it faced strong opposition from groups who wanted to tighten restrictions on currency manipulation which they said could offset the profits brought by the projected trade deal of US \$ 295 billion in annual savings. Other TPP critics also state that the TPP lacks transparency in its negotiations, as well as provisions on intellectual property that they claim can limit growth and innovation in developing countries and can raise prices. This phenomenon could be months or maybe years before the TPP itself can be said to develop. While TPP negotiations stopped, AIIB moved quickly. Despite this, it is also a challenge for China with ongoing Chinese territorial disputes with neighbors in the South China Sea and on the other hand can cause diplomatic problems between the main founding members.

But in the end, the Asia-Pacific Economic Cooperation (APEC) forum, which became an important milestone in maintaining stability, especially in the economic and security sector in the Asia Pacific region. Both China and the US are members, in addition to being able to provide opportunities for Pacific trade partnerships involving the two largest economies in the world, they can also balance a longer position of stability if the power is relatively balanced. 
Whatever the approaches outlined above, one thing is clear - the economies of the AsiaPacific region are growing fast, and increasingly seeking regulatory and harmonization cooperation to enhance their long-term success.

\subsection{Analysis of the Role of Indonesia as a Balancer Among The United States and China at the APEC Forum}

Indonesia having relations with the United States and China is not only limited to the APEC forum. Long before that, Indonesia had established a long relationship with the two countries. In addition, Indonesia maintains a strong commitment to the basic principle that the country must adopt a "free and active" foreign policy. This commitment means that Indonesia will not enter into formal alliances, but will actively pursue enhanced bilateral relations with the United States and China.

Since independence, Indonesia has maintained relatively cooperative and mutually supportive relations with the United States. The current security partnership is limited by Indonesia's operational and strategic capacity and the desire to maintain a variety of cooperative relationships. Indonesia's relations with China have experienced a sharp shift. However, Indonesia still strives to benefit from closer economic relations with China, which has increased economically in recent years.

As we know, China first announced plans for the new Asian Infrastructure Investment Bank (AIIB) at the APEC meeting in Bali in 2013. In addition to responding to the real need for massive expenditure on infrastructure throughout the region, this initiative also fits with China's economic diplomacy and the aim is to project a greater influence in the multilateral context. According to The Economist, Chinese initiative: start a heated diplomatic battle. America has lobbied allies not to join AIIB, while Jin Liqun, the Chinese official who will lead the bank, has persuaded many countries to register.

But the real tension, which is not mentioned is stemming from a deeper shift: China will use new banks to expand its influence at the expense of America and Japan, Asia's wellestablished powers. AIIB is "just one of many initiatives led by Beijing that is intended to undermine US involvement in Asia, part of a strategy that seeks to bring states to trial by Washington under the wing of China."

Although it is rumored to get opposition from America, AIIB was launched at the APEC Beijing meeting in October 2014. The United States has refused to pressure others to withhold support for banks. However, Australian news media reported that John Kerry personally asked the Australian Prime Minister to keep Australia away from banks. Both Australia and South Korea are among the 21 countries that attended the ceremony to launch AIIB as prospective members. Formally, the Australian government overrides concerns over the structure and process of bank governance. Indonesia was also specifically absent from the launch ceremony in Beijing, causing much speculation. However, the most likely interpretation of the absence of Indonesians is only the chaos associated with the change to a new government. Not long after Indonesia's absence at the Beijing launch was noted, the Minister of Finance said, "God willing, we will join. The president has given signs of approval. " Then in November, Indonesia formally confirmed its involvement, with the finance ministry stating that Indonesia would be involved in the preparation of AIIB operations and the formulation of the draft Articles of Agreement and to provide technical support.

Jokowi clearly supports the greater role of the Chinese economy in the region. $\mathrm{He}$ reportedly asked Chinese President Xi Jinping for a greater role for Chinese state-owned enterprises in developing Indonesia's infrastructure. Regarding AIIB, he seems to propose a 
bigger role for Indonesia and suggests banks to be headquartered in Indonesia. According to an Indonesian commentator and lecturer at the University of Indonesia, Shofwan Al Banna Choiruzzad, "With the approach of China getting closer, Indonesia invites balancing actions from the United States and its allies. By doing that, it hopes to expand its options in various policy arenas. " The immediate need for access to finance is a separate motive, but some Indonesian commentators remain suspicious of the Chinese influence along with the funding, stating that this could be politically risky.

Indonesia's foreign policy is characterized by trust and ambition. This belief reflects the relatively benign external security environment and the ambition reflects the long-standing desire to exercise regional and international leadership. Although limited by limited material resources, Indonesia maintains a strong commitment to the basic principle that the country must adopt a "free and active" foreign policy. This commitment means that Indonesia will not enter into formal alliances, but has actively pursued enhanced bilateral relations with other countries, particularly the United States and China. Tensions and competition in US-China relations, including those involving the South China Sea, created concern among Indonesian foreign policy makers who in turn sought to ensnare the two countries in various regional institutions and deepen bilateral involvement.

Indonesia's attitude about US-China relations is the preference for no greater power in Southeast Asia, which is expressed through the concept of "dynamic balance." Nevertheless, historically, Sino-Indonesian relations have been more problematic and lack the warmth and familiarity of the United States and Indonesia. The formation of Indonesia's foreign policy also tends to be more cautious towards China than the United States.

However, according to the analysis of the authors who use the concept of interdependence and Neoliberal Institutionalism theory, it can be concluded that the concept of interdependence which states the state is not an independent actor as a whole, but states that are interdependent to each other. No country as a whole can meet its own needs, each depending on the resources and products of other countries. As discussed earlier, Indonesia, the United States and China before joining the APEC forum had held bilateral cooperation between the two countries. Then, joined in the APEC forum where in fact nothing more than a forum for countries to be able to meet each other's needs and national interests.

The regulations or policies contained in the APEC forum actually do not guarantee the creation of a balance among its members. However, with a sense of need for one another, a sense of interdependence arises which causes member states to be bound to one another in the APEC forum. The interdependent relationship will make discussion of low politics (environment, pandemic diseases, poverty) more dominant than high politics (war, peace, border areas, security) on the global scene. That way, the state of interdependent relations makes countries more cooperative in solving problems.

We can see now, how the link in the APEC forum is not only focused on the issues that are said to be high politics in the region. However, also on other issues that need attention. Indonesia's role as a counterweight between the United States and China is inseparable from the interdependence of relations created between the two. Although the dominance and pressure of the two countries that have more power sometimes makes the atmosphere in the Asia Pacific region, in particular, look vulnerable unstable both in terms of politics, security and economy, but the role of Indonesia and other countries that are culturally policy its diverse foreign policy actually makes this interesting.

Differences in ideology and foreign policy concepts of various kinds adopted by member countries can later divert public opinion in the APEC forum which can balance stability in the forum and in the Asia Pacific region. In line with the assumption by Neoliberal Institutionalists, where the state ultimately makes and voluntarily submits to an institution that has a collective goal and builds a mechanism to achieve it. Informal institutional 
arrangements, or regimes, are also voluntarily made by the state and constitute an implied and explicit set of principles, norms, rules and procedures where the expectations of actors meet in certain issue areas.

Therefore, it can be said that the balanced position of the United States and China in APEC is inseparable from the shared values made voluntarily by member states including Indonesia, which creates a stable and balanced position due to interdependence that leads to the process cooperative.

\section{Conclusions and Recommendations}

APEC is one of the answers from countries in the Asia Pacific region in particular, to overcome the crisis that occurred after the Cold War. Where countries ultimately choose to cooperate with each other and create a pattern of interdependence that is wrapped up by an institution where values and regulations are created and applied together.

Even so, not infrequently we encounter, the dominance of the super power countries can ignore it. Not infrequently an institution or institution becomes an important gap and instrument of how political, economic interests and so on can be launched. Sometimes it benefits certain parties at the expense of others. This will certainly create an unstable condition both in direct cooperation and in a forum such as APEC, for example.

APEC could be a strategic position for Indonesia, the United States and China in meeting their national needs and interests. However, as a regional forum, APEC has different characteristics from other forms of regional economic cooperation forum. APEC is nonbinding. Decisions are obtained by consensus and the commitment to implement them is based on voluntarism. In addition, APEC is also based on consultative principles, comprehensive, flexible, transparent, open regionalism and recognition of differences in development between developed and developing economies

Considering this, of course this could be an opportunity or even vice versa for Indonesia. Inappropriate policy making in the APEC forum will be very vulnerable to influence in broad outline the political and economic dynamics of member countries and regions. Because, not binding causes each member country is able to voice their opinions as optimal as possible. Perhaps, the greatest risk if the vote comes from super power countries where often its dominance causes other countries to bow before him. However, on the other hand, assisted by the characteristics of developing countries which are not formally politically oriented between the United States and China where this will create a neutral opinion process in the APEC forum and various points of view of state ideology will help the cooperative process and a sense of interdependence because they both need each other will create a stable relationship.

It is quite impressive how Indonesia plays an active role in creating a stable region and contributes to developing APEC into a forum for economic cooperation that is progressing better. Indonesia's biggest contribution in APEC, one of which helped formulate APEC's main vision which is also called the Bogor Goals. This commitment is the basis of various initiatives to encourage the acceleration of the elimination of trade and investment tariffs among APEC members.

Indonesia's participation in APEC gave rise to a variety of opinions from observers and writers who conducted research on the impact of APEC on Indonesia. various opinions are of course different, some are optimistic and pessimistic. The pessimists felt that APEC did not have an economic impact on Indonesia and even tended to be an instrument for industrialized countries to launch their economic interests and disadvantaged developing countries, especially Indonesia. Some even argue that APEC seems to have been suspended as 
an international organization. But there are also groups who are very optimistic that Indonesia will benefit from joining APEC. This certainly depends on how Indonesia is able to influence public opinion and be selective in reviewing the policies that will be agreed at the APEC forum. 


\section{REFERENCES}

\section{Books}

Jackson, Robert, dan Sorensen, George. 2013. Introduction to International Relations: Theories and Approaches. United Kingdom: Oxford University Press.

Janik, Laura, dan Sterling-Folker, Jennifer. 2011. International Encyclopedia of Political Science: Chapter Neoliberal Institutionalism. Thousand Oaks: Sage Publications, Inc.

\section{Journals}

Atiqah. 2017. "Sejarah APEC dan Tantangan yang Dihadapinya". Journal Equitable Vol 2 No 1. Accessed on 04 April 2020: http://ejurnal.umri.ac.id/index.php/JEQ/article/view/821

Hamilton, Natasha, and McRae, Dave. 2015. "Indonesia: Balancing the United States and China, Aiming For Independence". The United States Studies Centre. Retrieved from https://www.usindo.org/wp-content/uploads/2015/12/Indonesia-Balancing-US-andChina-November-2015-MacArthur-Indonesia-ONLINE.pdf

Hirano, Akiko. 1996. "Legal Aspects of the Institutionalization of APEC". IDE-APEC Study Center Working Paper Series 95/96-No 6. Retrieved from https://www.ide.go.jp/library/English/Publish/Download/Apec/pdf/1995_05.pdf

Polii, Restilia. 2015. "Kepentingan Indonesia Bergabung Dalam APEC". Jurnal Polinter: Kajian Politik dan Hubungan Internasional Vol 1 No 1. Accessed on 04 April 2020. http://journal.uta45jakarta.ac.id/index.php/polhi/article/view/64

Prasetyo, Sigit Aris. 2011. "APEC dan Proses Integrasi Ekonomi Regional di Kawasan Asia Pasifik". Jurnal Kajian Wilayah LIPI Vol 2 No 2. Retrieved from http://jkw.psdr.lipi.go.id/index.php/jkw/article/view/330/201\#

Putri, Adinda Normala. 2019. "Persaingan Pengaruh Pasifik Selatan: Pengalihan Dukungan Diplomatik Kepulauan Solomon Dari Taiwan Ke Tiongkok". Journal Asia Pacific Studies Vol 3 No 2. Accessed on 06 April 2020.

http://ejournal.uki.ac.id/index.php/japs/article/view/1294/1100

Wardhani, Baiq L. S. W., “APEC 2020 Bagi Indonesia: Mitra atau Pemangsa?”. Journal Masyarakat, Kebudayaan dan Politik UNAIR Vol 19 No 4. Accessed on 06 April 2020.

http://journal.unair.ac.id/filerPDF/APEC\%202020\%20BAGI\%20INDONESIA.pdf

\section{Websites}

Lumanauw, Novi, dan Syukro, Ridho. 2019. "Indonesia Penyeimbang AS-Tiongkok di Asia Pasifik". Berita Satu, 25 April 2019. Accessed on 06 April 2020.

https://www.beritasatu.com/ekonomi/550669-indonesia-penyeimbang-astiongkok-diasia-pasifik

Mata Mata Politik. 2018. "Opini: Bagaimana Indonesia Berpotensi Jadi Jembatan China dan Amerika Serikat di Asia”. Mata Mata Politik, 10 April 2018. Accessed on 06 April 2020. https://www.matamatapolitik.com/opini-bagaimana-indonesia-berpotensi-jadijembatan-china-dan-amerika-di-asia/ 